\title{
ENRICHMENT OF MINERAL VEINS BY LATER METALLIC SULPHIDES*
}

BY WALTER HARVEY WEED

(Presented before the Society December 30, 1899)

\section{CONTENTS}

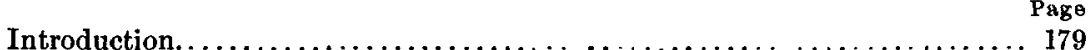

Scope of paper........................................... 180

Definition of sulphide enrichment........................... 180

Zone of oxidation. ......................................... 181

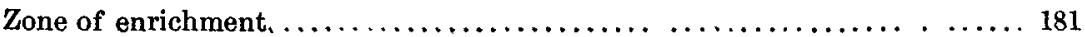

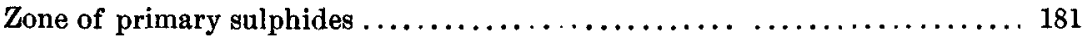

Enrichments described by previous writers. ................... 182

Chemical changes...................................... 183

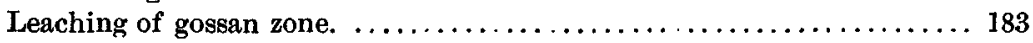

Deposition of material from solution in the enrichment zone $\ldots \ldots \ldots \ldots 186$

Mineral alteration.................................... 189

Summary of chemical and mineralogic evidence................ 194

Mode of occurrence of deposits of secondary sulphide ores............ 194

Method adopted of presenting the subject....... . . . . . . . . . 194

Copper........................................... 195

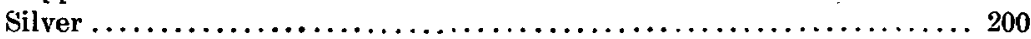

Zinc................................................ 205

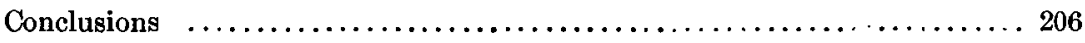

\section{INTRODUCTION}

In the early history of the development of many ore deposits, especially those of silver and of copper, masses of rich sulphide ore are encountered which lie below the limit of surface decomposition, and which are very often soon passed through in mining and found to give place more or less abruptly to comparatively poor and base sulphide ores. In other cases "bonanzas" are encountered, which in many instances consist of rich ores of a mineralogic character wholly unlike the

* Published by permission of the Director of the U. S. Geological Survey. Abstract printed in program of meeting December, 1899. 
main mass of the mineral deposit; or sometimes fissures in a low grade ore are filled by a rich ore. Such masses are believed to be generally of later origin than the original vein filling, and as they enrich the vein they are designated as sulphide enrichments.

\section{SCOPE OF PAPER}

This paper is an attempt to explain the genesis of such bodies of sulphide ores as enrichments formed by the redeposition of material leached from the vein, generally by superficial waters, and to show the chemical and mineralogic changes involved in the processes and the physical conditions under which the ores have been deposited.

Not only is the process one that has played an active part in the later history of ore deposits, but a consideration of its effects leads to a review of the changes in the history of the vein, more especially in regions where marked changes of water level have resulted from physiographic revolutions. At an early date I hope to present a clear illustration of the importance of this change of level in the ore deposits of Butte, Montana, where for some time past a study of the copper veins has been made by Professor S. F. Emmons and myself for the United States Geological Survey.

In the present paper I attempt to prove-

1. That the leaching of a relatively lean primary ore, commonly by surface waters (but it may be by deep seated waters), will supply the material in solution for such enrichment.

2. That the unaltered sulphides, especially pyrite, will induce precipitation; that the material precipitated is crystalline; and that a number of mineral species are commonly formed, and are now forming, in veins by such reactions.

3. That such minerals deposited in quantity may form ore bodies of considerable size (bonanzas) or may be disseminated through the lean primary ore in strings and patches, thus enriching the ore body as a whole and even making a former low grade body of sufficient value to work.

\section{Definition of Sulphide Enrichment}

By secondary sulphide enrichment is meant the concentration of the metals into high grade sulphide ore bodies. It differs from what is often called secondary enrichment (enrichment in which the character of the ore is improved by the removal of its worthless constituents and the nonremoval of the valuable metals), and it should not be confused with that enrichment due to circulating surface waters which results in the forma- 
tion of masses of oxide, carbonate, sulphates, chloride or bromide ores, which are enrichments whose origin is more clearly apparent and about which there is no doubt. The latter deposits belong to the zone of oxidation proper and are the commonly accepted products of superficial alterations of ore deposits. Their mineral character is in sharp contrast to that of the sulphides, sulpharsenites, and sulphantimonides which form the subject of this paper.

\section{ZONE OF OXIDATION}

The upper parts of ore deposits are generally more or less changed by atmospheric agencies and rarely show the same mineralogic and physical features that prevail in the lower part of the deposit. If the original deposit holds much pyrite the outcrop is often a mass of impure limonite, the "iron hat" or "gossan" of the mines. Lower down the altered, ironstained vein matter contains the carbonates, oxides, and other ores resulting from oxidation. This uppermost part of the vein, which is often the most remunerative to work, especially in gold veins, is here designated the zone of oxidation, as oxidation has been complete in it. This zone practically corresponds to that of superficial alteration of most writers, though, as will be shown, it is really only the upper part of the portion traversed by downward seeping surface waters.

\section{ZONE OF ENRICHMENT*}

Beneath the zone of oxidation and between it and the unaltered primary vein matter lies the zone of enrichment. Its upper limit is usually very sharply defined, and may be told by contrast with the rusty color of the overlying deposit, though there is no definite plane, but usually an extremely irregular boundary. The lower limit of the zone of enrichment is also very irregular, though in some cases it is sharply defined. Generally, owing to a fracturing of the original vein matter, the secondary sulphides occur in cracks and crevices extending down into the primary ore, even as far as many hundred feet, especially along fault planes which have become channels for descending waters.

\section{ZoNe of PRIMARY SUIPHIDES}

The lowest part of the vein, below the permanent ground water level, consists of the unaltered sulphides which compose the original ore of the vein. This part constitutes the zone of primary sulphide ore.

\footnotetext{
* 'This term has been already used by Kemp in discussing the chalcocite bodics of the Butte (Montana) copper veins. See Ore Deposits of the United States, New York, 1896, p. 163.
} 
It is, perhaps, unnecessary to add that while sulphide enrichment is believed to be a common phenomenon in veins; it is not an invariable accompaniment, but is very often wanting.

\section{Enrichmen'ts described by previous Writers}

The importance of this secondary sulphide enrichment seems to have escaped the attention of most geological writers, though such deposits are familiar to many practicing mining engineers. The most prominent of French writers on ore deposits, De Launay, has, it is true, recogmized this phenomenon, describing it as part of the phenomena of superficial alteration of ore deposits in an essay entitled "Contribution à L'Étude des Gîtes Métallifères." The second part of his paper is devoted to the phenomena of superficial alteration and of the renewal of migration in the constitution of ore deposits.* The recognition of the "renewal of migration" is the essential element of secondary sulphide enrichment. De Launay regards many vein fillings as formed by the direct leaching of preexisting ore deposits through a concentration of material. In the latter part of his paper De Launay gives a summary of what is known regarding the derivation and deposition of the various metals, and brings out the main facts upon which he bases his views.

Other writers have alluded in a casual way to this feature of ore deposits, Posepny, for example, says :

"The chemical effects proceeding from the present surface . . . involve not only the phenomena on the surface itself, but extend beneath it to ground water level and even below that level as far as the vadose circulation is traceable. $t$. . . The solutions formed by surface waters, like those of mine waters, mostly find their way to the point where the water level reaches the surface, yet as a part of the ground water penetrates to greater depths, such solutions may very likely produce in the deep region itself impregnations which must, however, differ in character from those produced by the deep circulation. $\neq$ Meteoric waters carrying oxygen, some carbonic acid, and minute amounts of chlorides will first oxidize whatever is oxidizable, especially metallic sulphides. The ferric sulphate formed by the decomposition of the easily attacked $\mathrm{FeS}_{2}$ will immediately attack the latter minerals of the series." ?

Penrose refers very briefly to this feature and says: "Hence the richest bodies of ore in a deposit often occur between the overlying altered part and the underlying unaltered part." II

* Sur le róle des phénomènes d'altération superficielle et de remise en mouvement dans la constitution de ces gisements. Ann, des Mines, xii, 1897, pp. 119-228.

† Genesis of ore deposits, pp. 135, 136.

$\ddagger$ Loc. cit., p. 136.

\& Loc. cit., p. 137.

\|The superficial slteration of ore deposits. Jour. of Geology, vol, ii, p. 294. 
Emmons has ascribed the origin of the great bodies of rich copper sulphides at Butte, Montana, to secondary deposition and transportation, and gives a very clear outline of the possible changes. For copper ores, however, there seems to have been for many years a general belief in secondary deposition based upon the generally accepted explanation of the origin of the black copper (sulphide) ores of Ducktown, Tennessee, as derived from the material leached out of the part of the vein now forming the gossan.

Kemp also says that the upper 400 feet of the Butte veins is leached of copper, while below are found the bornite and chalcocite bodies of the zone of enrichment.

Upon reviewing the literature of ore deposits the writer has been impressed with the almost total lack of evidence to show that secondary minerals might be formed by such leaching or decomposition of vein matter. In many cases bodies of rich ore are mentioned and their structural features and occurrence described, but no evidence of secondary derivation is given.

\section{Chemical Changes}

\section{LEACHING OF GOSSAN ZONE}

The superficial alteration of ore deposits, by which the upper part of a mineral vein is altered and decomposed, has been discussed by many writers and has recently been fully treated by Penrose.* It is, however, necessary to consider briefly the reactions involved, since the origin of the secondary sulphides lying between the gossan and the unaltered, original vein matter is usually due to descending-that is, surfacewaters. In general, it may be stated that in many instances the secondary ores are deposited above the level of deep seated water, the socalled "permanent water level," but in others the surface waters descend by water-courses and channels below the general level of the uprising deep waters, and all such waters eventually mingle with them.

Surface waters descending through the relatively porous and open textured gossan of a vein are normally oxidizing, and on passing downward usually attack the unaltered sulphides and deepen and extend the zone of the gossan. As the waters descend they are robbed of their oxygen by the sulphides which they decompose, and percolating further downward the waters which at first were strongly oxidizing in character are now charged with various salts and frequently with free sulphuric acid. $\dagger$

* Jour. of Geology, vol. for April-May, 1894, p. 288. See also Emmens in Engineering and Mining Journal, vol. 54, December 17, 1892, p. 582.

tAs, for instance, mine waters run through precipitating tanks at Butte, the zinc-bearing waters of Missouri, etcetera. Am. Jour, Sci, vol. xliii, May, 1892, p. 418. 
They are still descending waters of surface origin, but have lost all the characters commonly ascribed to surface waters. This change is, of course, due to the reactions involved in the changing of the vein minerals to gossan. The common metallic sulphides of veins are pyrite, pyrrhotite, chalcopyrite, tetrahedrite, enargite, bornite, galena (with which quartz is most commonly associated as a gangue mineral) and a little less commonly calcite and other carbonates, and barite, etcetera. The changes by which this mixture is converted into a mass of porous, more or less pure limonite are briefly as follows: The pyrite alters to a mixture of iron sulphates and sulphuric acid, which, reacting on more pyrite, eventually forms a mixture of hydrated oxides (limonite ores). The reactions commonly assumed are as follows:
1. $\mathrm{FeS}_{2}+\mathrm{O}_{3} \div \mathrm{H}_{2} \mathrm{O}=\mathrm{FeS}+\mathrm{H}_{2} \mathrm{SO}_{4}$.
2. $\mathrm{FeS}+\mathrm{H}_{2} \mathrm{SO}_{4}=\mathrm{FeSO}_{4}+\mathrm{H}_{3} \mathrm{~S}$.
3. $\mathrm{FeS}_{2}+\mathrm{O}_{2}+2 \mathrm{H}_{2} \mathrm{~S}=\mathrm{FeS}+2 \mathrm{H}_{2} \mathrm{O}+3 \mathrm{~S}$.
4. $\mathrm{S}+\mathrm{O}_{3}+\mathrm{H}_{2} \mathrm{O}=\mathrm{H}_{2} \mathrm{SO}_{4}$.
5. $2 \mathrm{Fe}_{2} \mathrm{SO}_{4}+\mathrm{O}+\mathrm{H}_{2} \mathrm{SO}_{4}=\mathrm{Fe}_{2}\left(\mathrm{SO}_{4}\right)_{3}+\mathrm{H}_{2} \mathrm{O}$.
6. $\mathrm{FeS}+\mathrm{Fe}_{2}\left(\mathrm{SO}_{4}\right)_{3}=3 \mathrm{FeSO}_{4}+\mathrm{S}$.

Pyrrhotite, if present, is attacked as in the second equation given. Chalcopyrite and bornite are commonly assumed to consist of $\mathrm{Cu}_{2} \mathrm{~S}$ and $\mathrm{Fe}_{2} \mathrm{~S}_{3}$. The iron sulphide molecule is attacked and dissolved by the ferric sulphate present in the water, leaving $\mathrm{Cu}_{2} \mathrm{~S}$ as an amorphous, sooty material. It is well known that ferric sulphate will attack and decompose metallic sulphides. It has been shown* that the order of attack will be first chalcocite, then galena, then blende, the reactions being of the same character as those by which the iron sulphide is attacked. The $\mathrm{Cu}_{2} \mathrm{~S}$ left by the alteration of the chalcopyrite is in turn attacked by the ferric sulphate, forming cupric sulphate, ferrous sulphate, and sulphur. Lead, zinc, and other metallic sulphides are in their turn attacked by ferric sulphate, forming a sulphate of the metal, together with ferrous sulphate and sulphur, the latter, of course, oxidizing at once to $\mathrm{SO}_{2}$ and sulphuric acid.

"It is therefore evident that all the metallic sulphides will be dissolved away, and were it not for further oxidation of the iron, gangue alone would be left. The process has been stated to be $12 \mathrm{FeSO}_{4}+6 \mathrm{O}+\mathrm{H}_{2} \mathrm{O}=4 \mathrm{Fe}_{2}\left(\mathrm{SO}_{4}\right)_{3}+2 \mathrm{Fe}_{2} \mathrm{O}_{3}, \mathrm{H}_{2} \mathrm{O}$; that is, as no further supply of free sulphuric acid (or sulphur) is available, the ferrous sulphate can not form ferric sulphate and is therefore precipitated as in the equation and partly as a basic sulphate, $6 \mathrm{FeSo}_{4} \mathrm{O}_{3} 3 \mathrm{Fe}_{2} \mathrm{O}_{3}\left(\mathrm{SO}_{3}\right)_{2}$ an insoluble yellow substance precipitated from ferric hydrate and found also in nature." $\dagger$

* Emmens : Chemistry of gossan. Engineering and Mining Journal, vol. 54, December 17, 1892. $\dagger$ Loc. cit., p. 583. 
In very many cases that have come under the writer's notice chalcopyrite and pyrite carrying copper are seen altering to a soft, black, sooty substance which soils the fingers and is pulverulent when dry. This proves to be cupric sulphide when tested in the laboratory, but it is not crystalline. Its formation is readily understood if we accept the explanation just given of the alteration of chalcopyrite. Chalcopyrite being $\mathrm{Cu}_{2} \mathrm{~S}, \mathrm{Fe}_{2} \mathrm{~S}_{3}$, the iron sulphide molecule yields more readily to attacking solutions of ferric sulphate (which by hydrolysis are acid) than the cupric sulphide, and the iron is removed and $\mathrm{Cu}_{2} \mathrm{~S}$ left as the amorphous powder seen. This is said to occur because copper has a "very much greater affinity for sulphur than iron."* After the greater part of the iron is gone, or rather converted to sulphate, the ferric sulphate solution attacks the $\mathrm{Cu}_{2} \mathrm{~S}$, forming the amorphous powder seen, and removes it in turn, and it is carried a greater or less distance before it is redeposited. In the Gold Hill (Rowan county, North Carolina) specimens the copper sulphide has not been carried far, and in a large measure has by the gradual lowering of the limit of oxidation been converted to oxide and carbonate and native copper. Hand specimens collected by me show all the stages of this alteration.

As the sulphate of lead is virtually insoluble in water, it can only be carried downward to form transposed, redeposited sulphides by an intermediate change to the carbonate through carbonate of lime, namely, $\mathrm{PbSO}_{4}+\mathrm{CaCO}_{3}=\mathrm{PbCO}_{3}+\mathrm{CaSO}_{4}$. This carbonate is soluble in waters charged with carbon dioxide, but is precipitated by carbonate of lime as lead carbonate. Galena is also dissolved by copper sulphate, as shown by experiments in which, after eleven months' immersion, the galena was etched, and lead sulphate and a subsulphate of copper was formed. $\dagger$ If the vein contains much pyrite, supplying an abundance of iron sulphate, the upper part of the vein will be leached of all its valuable metals, including gold and silver, as it is well known that ferric sulphate dissolves with great ease, not only the copper sulphides, but also the small content of precious metals of the ore, the reactions being similar to those just given. $\$$ If the amount of ferric sulphate present is relatively small, copper oxide and carbonates will be formed in the lower part of the gossan and in cracks and fissures in the underlying sulphide ores, be they original or secondary.

That the metals are leached out of the gossan and go into solution is well known at almost all copper mines. For other metals the evidence

\footnotetext{
* The series is $\mathrm{Hg} \mathrm{Ag} \mathrm{Cu} \mathrm{Sb} \mathrm{Sn} \mathrm{Pb} \mathrm{Zn} \mathrm{Ni} \mathrm{Co} \mathrm{Fe} \mathrm{As} \mathrm{Mn} \mathrm{(E.} \mathrm{\&} \mathrm{M.} \mathrm{Jour.,} \mathrm{Oct.} \mathrm{25,} \mathrm{1890,} \mathrm{p.} \mathrm{484).}$ See F. Sandburger: Untersuchungen über Erzgänge, 1882, and Vogt: Zeitschrift für Praktische Geologie, vol. i, 1893, p. 262.

† Compte Rendu, vol. xx, 1845, pp. 1509-1536.

† Vogt : Zeitschrift für Praktische Geologie, July, 1899
} 
is also abundant. The composition of a surface water filling a mine shaft 130 feet deep, noted by Haworth,* the spring water of unquestioned superficial character from Missouri, analyzed by Hillebrand, $\dagger$ and a great many analyses of vadose waters, published by Emmons $\ddagger$ and various other writers, establish this fact beyond a doubt.

If other proof were needed, the stalactites formed in mines afford convincing evidence of the solubility of metallic sulphides in deoxidized waters. Stalactites of blende and of galena are found in the mines of Missouri. The percolating waters of many copper mines deposit stalactites of hydrated iron oxide, and of copper and aluminous sulphates. Such deposits have been found in the Copper Queen mine near Bisbee, Arizona, and at Butte, Montana. Douglas describes a spring water which oozes from feldspathic rocks at the copper basin, Yavapai county, Arizona.§ On exposure to the air an insoluble mass separates out which has the composition given below :

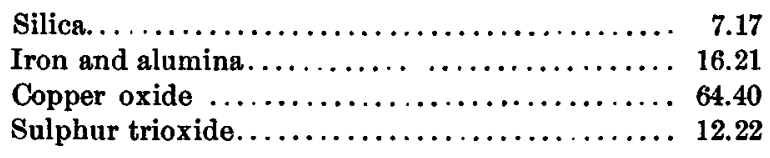

In time this sludge is converted into a mixture of carbonate of copper and alumina that binds together the gravel into a conglomerate.

Sulphide of zinc unquestionably formed by the action of cold sulphuretted water coming in contact with an aqueous solution of zinc sulphate has been found at Galena, Missouri. The deposit was amorphous, and an analysis by J. Dawson Hawkins showed the following composition : \|

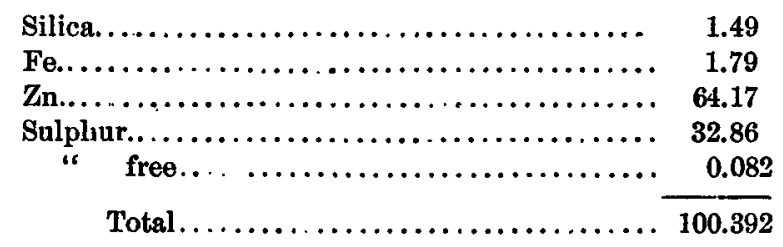

DEPOSITION OF MATERIAL FROM SOLUTION IN THE ENRICHMENT ZONE

When the waters holding the metals in solution trickle down into cracks and crevices of the underlying pyritous ore the ferric sulphate is reduced to ferrous sulphate, and the gold, silver, and copper are precipitated. $\uparrow$

\footnotetext{
* Geology of lead and zine district of Cherokee county, Kansas, 1884, p. 34.

† Am. Jour. Sei., vol. xlii, May, 1892, p. 418.

¥ Mines of Custer county, Colorado, Seventeenth Ann. Rep. U. S. Geol. Survey, 1896, p. 411 et seq. ¿ Trans. Am. Inst. Mining Engineers, February, 1899, p. 25 of pamphlet edition.

|f Malvern W. Iles : Engineering and Mining Journal, vol. 49, March 5, 1899, p. 499.

I Vogt: Das Huelva Kiesfeld, Zeitschrift für Praktische Geologie, July, 1899, p. 250.
} 
Though the reduction of copper sulphate to chalcocite does take place to a limited extent in the oxidized zone, where the glance is generally soon changed to oxide, the great bodies of glance and bornite found beneath the water level are probably not formed in this way; they result from reactions which do not involve the presence of free oxygen, but depend on a reduction of the copper sulphide by pyrite from the sulphate solution. The experiments of Brown show that both pyrite and marcasite are decomposed by copper sulphate, and copper sulphide is formed.* According to the modern theory of 'solutions. cupric sulphate in solution undergoes partial electrolytic dissociation, forming $\mathrm{Cu}(\mathrm{OH})_{2}$ and $\mathrm{H}_{2} \mathrm{SO}_{4}$, the latter being ionized to $2 \stackrel{+}{\mathrm{H}}$ and $\stackrel{\overline{\mathrm{SO}}}{4}_{4}$, while part of the $\mathrm{CuSO}_{4}$ is ionized to $\mathrm{Cu}^{+}$and $\mathrm{SO}_{4}$. The writer has added $\mathrm{H}_{2} \mathrm{~S}$ to a solution of pure copper sulphate and obtained a precipitate of copper sulphide, and this is greatly increased in amount if some free $\mathrm{H}_{2} \mathrm{SO}_{4}$ be added. It has been asserted that pyrite when powdered and treated with very dilute sulphuric acid will give off sulphuretted hydrogen. Qualitative tests made for me by $\mathrm{Dr} H$. N. Stokes in the Survey laboratory upon perfectly pure pyrite failed to confirm this statement. If, however, pyrrhotite is added, hydrogen sulphide is at once evolved. It was found, however, that the pyrite from the Butte quartz veins, carrying mere traces of copper, when powdered and treated with dilute sulphuric acid gave off sulphuretted hydrogen, and that the purest chalcopyrite of Ducktown, Tennessee, and cupriferous pyrite of Gold Hill, North Carolina, behaved in the same way. It is therefore certain that the pyrite of these deposits is capable of precipitating copper sulphide from down seeping waters holding copper sulphate and sulphuric acid. This reaction might be expressed as $4 \mathrm{CuSO}_{4}+3 \mathrm{FeS}_{2}+4 \mathrm{H}_{2} \mathrm{O}=2 \mathrm{Cu}_{2} \mathrm{~S}+$ $3 \mathrm{FeSO}_{4}+3 \mathrm{H}_{2} \mathrm{SO}_{4}+\mathrm{H}_{2} \mathrm{~S}$, and for pyrrhotite, $2 \mathrm{CuSO}_{4}+2 \mathrm{FeS}=\mathrm{Cu}_{2} \mathrm{~S}+$ $2 \mathrm{FeSO}_{4}+\mathrm{S}$, while for chalcopyrite $2 \mathrm{CuSO}_{4}+\mathrm{Cu}_{2} \mathrm{SFe}_{2} \mathrm{~S}_{3}+\mathrm{H}_{2} \mathrm{SO}_{4}=$ $2 \mathrm{Cu}_{2} \mathrm{~S}+3 \mathrm{FeSO}_{4}+\mathrm{H}_{2} \mathrm{~S}$. The hydrogen sulphide would, of course, at once attack any $\mathrm{Cu}(\mathrm{OH})_{2}$ present in the water and form copper sulphide. In these reactions the influence of $\mathrm{FeSO}_{4}$ has for simplicity been left out. The $\mathrm{H}_{2} \mathrm{~S}$ formed by the decomposition of the pyrite will attack the metallic sulphates present and form sulphides, as shown by Doelter. $\dagger$

* Proc. Amer. Philos. Soc., vol. xxxiii, May 18, 1894.

$\dagger$ This investigator has made sulphides by the method of Senarmont, with the difference that he made them at temperatures below 100 degrees, and the time was extended over several days or weeks. As a starting point he frequently used minerals which contained one constituent of the product which was to be prepared. Thus small cubes of galena were formed from cerussite which was treated several days in a closed glass tube at a temperature of 80 to 90 degrees. In the same manner crystals of pyrite were formed from siderite, magnetite, or hematite; from cuprite, chalcocite. From malachite crystals of covellite were formed. (Translated from Chemische Mineralogie, Reinhard Braun, Leipzig, 1896, p. 266.) 
Doelter also states that by the reaction of sulphuretted hydrogen on a solution of silver chloride and antimoniate of potash in presence of carbonate of soda in closed tubes at 80 to 250 degrees,miargyrite $\left(\mathrm{Ag}_{2} \mathrm{~S}, \mathrm{Sb}_{2} \mathrm{~S}_{3}\right)$, pyrargyrite $\left(3 \mathrm{Ag}_{2} \mathrm{~S}, \mathrm{Sb}_{2} \mathrm{~S}_{3}\right)$, and stephanite $\left(5 \mathrm{Ag}_{2} \mathrm{~S}, \mathrm{Sb}_{2} \mathrm{~S}_{3}\right)$ were formed.* Silver sulphide, which is soluble in pure water, would be reduced by $\mathrm{H}_{2} \mathrm{~S}$, with precipitation of the sulphide, and the sulpharsenate and sulphantimonates of silver may be formed in a similar way. Zinc sulphate is reduced to blende in the same manner. Doelter says, in writing of the artificial production of these minerals, that dilute solutions are more favorable than concentrated. $\dagger$ Sulphate of zinc is at ordinary temperature almost as soluble as sulphate of copper, even in the presence of carbon dioxide. Bischof states that sulphates are precipitated by $\mathrm{H}_{2} \mathrm{~S}$, resulting in dark colored masses, but when precipitated from a dual solution to which $\mathrm{H}_{2} \mathrm{~S}$ has been added gradually there forms on the surface of the liquid a thin film with the metallic luster of galena. Putting this in a filter and washing, one finds after partially drying that there are small particles with metallic luster.\$ Although the sulphides prepared by precipitation from solutions of metallic salts are mostly amorphous masses without luster, they may be obtained artificially with metallic luster by the slow action of $\mathrm{H}_{2} \mathrm{~S}$ upon very weak solutions, or precisely the conditions which prevail in nature. $\uparrow$

Silver brought into solution by ferric sulphate acting on argentiferous galena, blende, or pyrite probably forms silver sulphate. If there is an excess of ferrous sulphate thus formed and, as no more easily attacked substance is available, the ferrous sulphate and the silver sulphate will then form native silver, viz: $\mathrm{Ag}_{2} \mathrm{SO}_{4}+2 \mathrm{FeSO}_{4}=\mathrm{Ag}_{2}+\mathrm{Fe}_{3}\left(\mathrm{SO}_{4}\right)_{3}$, and hencelin many cases whatever silver is found in the vein remains in the gossan and is not leached out and redeposited at lower levels. Where other conditions prevail redeposition occurs.

R. C. Hills has suggested that the silver and the gold carried downward by waters holding ferrous and ferric sulphates has been precipitated through the decomposition of the sulphates by feldspar.**

As noted by Vogt and other observers at Konigsberg, native silver is abundant, as an alteration product of silver glance, below the zone of oxidation. He suggests that where native silver occurs in minute cracks in the country rock at such depths it may result from the reducing ac-

\footnotetext{
* Braun's Chemische Mineralogie, p. 267.

†C. Doelter : Allgemeine Chemische Mineralogie, Leipzig, 1800, cliap. iv, p. 105 et seq.

† De Launay : L'argent, p. 70.

8 Braun's Chemisehe Mineralogie, p. 260.

If Bishop: English Trans., vol. iii, p. 451.

** Proc. Colorado Scientific Society, vol. i, p. 32.
} 
tion of ferrous silicates.* Spurr found native silver occurring in similar situations at Aspen, Colorado.

In the lead mines of Missouri, Jenney says that the lead and zine brought into solution by oxidizing waters are reduced and precipitated as sulphides by organic matter in the presence of alkaline sulphates, $\mathrm{PbO} \mathrm{CO}{ }_{2}+\mathrm{CaO} \mathrm{SO}_{3}+\mathrm{H}_{2} \mathrm{~S}+2 \mathrm{C}=\mathrm{PbS}+\mathrm{CaO} \mathrm{SO}_{3}+2 \mathrm{CO}_{2} \dagger+\mathrm{H}_{2} \mathrm{O}$.

\section{MINERAL ALTERATION}

A study has been made both in the field and office of the changes which take place in the alteration of the primary sulphides and of the paragenesis and the association of the redeposited (secondary) sulphides. The data are more abundant for copper than for the other metals because the facilities have been more abundant for the observations of such deposits, and many notes have been gathered in brief trips to Southern copper mines during the past four months. Dana says chalcopyrite alters to bornite, and bornite to chalcocite. I have observed the following alterations: Chalcopyrite to chalcocite, this to cuprite, this to malachite, and the latter to chrysocolla; also malachite to tenorite, and cuprite to native copper. Bornite is seen altering to chalcocite and hematite. The oxide and carbonate are, of course, formed only by superficial alteration, but native copper, like native silver, is found in places where its formation must be ascribed to the deep-seated reactions, not to oxidizing waters.

The black copper of Ducktown and Ore Knob obtained from the $\mathrm{Na}$ tional Museum collection, as well as that collected by the writer at the mines, is proven by chemical tests made in the United States Geological Survey laboratory to be entirely chalcocite.

The fact that copper glance may be of secondary origin is not generally recognized, and has been denied by some geologists. Of this an examination of the specimens leaves no doubt whatever. Not only is the cupric sulphide formed by the alteration of chalcopyrite and bornite through the agency of descending surface waters, but the material is actually taken into solution and transported and redeposited as crystalline glance. In literature the first mention of crystalline material thus formed is in an account of the Ducktown material by Sterry Hunt, who states that crystals of glance were seen by August Raht in druses in the ore. In this ore, however, I myself have been unable to find any crystallized material, even after a very careful search on the ground.

The unequaled chalcocite crystals of the Bristol, Connecticut, copper

* Jour. Praktische Geologie, April, 1890, p. 250.

$\dagger$ W. P. Jenney, in Trans. Am. Inst. Mining Engineers, 1893, p. 202. 
mine occur in the oxidized zone,* and copper glance pseudomorphous after chalcopyrite in the quartz veins near Georgieff, in the Altai mountains, is described as occurring with hematite, chrysocolla, and malachite; also derived from copper pyrite. $\dagger$

Emmons and Tower have stated $\ddagger$ that chalcocite "occurs filling fractures in pyrite and chalcopyrite, and from its relation with these minerals and bornite it is certain that it is derived from the two latter minerals by decomposition, and is therefore later than these minerals." Bornite is also mentioned by the same writers as an alteration product of chalcopyrite.

Kemp has called attention $\S$ to the "general experience that the carbonates form most readily when the original sulphides are in limestone, whereas when granite or some similar crystalline rock constitutes the walls chalcocite or bornite results."

With these exceptions, I have not found in the abundant literature of mineral alteration and mineral synthesis any reference to the formation of crystalline glance by secondary alteration. I have therefore been somewhat surprised to find abundant evidence of it in copper ores, not only at Butte, but elsewhere in Montana, and also in the ores of North Carolina and Virginia. The glance so found is in all conditions: amorphous, massive without crystalline texture, massively crystalline, and in crystals.

Native copper, though commonly considered as a product of oxidizing waters only, also occurs, as already noted, under conditions which show that it has been produced far below the zone of oxidation and where no oxygen has been present. Thus Douglas has described || native copper as occurring in the Copper Queen mine, " not at the surface, where oxidizing agencies have been most active, but in the deepest layers of the large ore bodies, where apparently some reducing agent has been more actively at work than elsewhere and where the ore is farthest removed from atmospheric disturbance." In my own examinations I find that the native metal frequently occurs under similar conditions at many localities. It is not necessary, however, to suppose any new conditions, and the deposit is easily understood if, as is commonly the case, ordinary limestone be present. The carbonate of lime will reduce the copper sulphate to cuprous oxide, and this with either sulphuric acid or ferrous sulphate will form native copper, as shown by the following equations :

* Silliman and Whitney, Am. Jour. Sci., $2 d$ ser., vol. $x x$, p. 361.

† Jeremeef : Bull. Acrdemy of Sciences, St. Petersburg, 1897, v. 6, p. 37 ; quoted in Zeitschrift Kryst. Mineralogie, 1899, v. 31, p. 508.

† Under "Paragenesis," in Butte Special Folio, folio 39, U. S. Geological Survey.

8 Ore Deposits of the United States, 2d ed., New York, 1896, p. 164.

$\|$ Trans. Am. Inst. Mining Engineers, February, 1899. 
$2 \mathrm{CuSO}_{4}+2 \mathrm{CaCO}_{3}=2 \mathrm{CuO}+2 \mathrm{CaSO}_{4}+2 \mathrm{CO}_{2}$. The $\mathrm{CuO}$ is reduced to $\mathrm{Cu}_{2} \mathrm{O}$ by organic matter in the limestone.

$\mathrm{Cu}_{2} \mathrm{O}+\mathrm{H}_{2} \mathrm{SO}_{4}=\mathrm{Cu}+\mathrm{CuSO}_{4}+\mathrm{H}_{2} \mathrm{O}$ or else $3 \mathrm{Cu}_{2} \mathrm{O}+3 \mathrm{FeSO}_{4}=6 \mathrm{Cu}+\mathrm{Fe}_{2} \mathrm{O}_{3}+$ $\mathrm{Fe}_{2}\left(\mathrm{SO}_{4}\right)_{3}$.

Specimens collected from the Union Copper company's mine at Gold Hill, North Carolina, are especially interesting. 'The primary ore is a rather fine grained gray quartz carrying small bunches, strings, and shreds of chalcopyrite.

The ore body is fractured by vertical planes down which the surface waters percolate and alter the vein, forming the well defined zone of oxidized ores and penetrating to a greater or less depth along the vertical cracks. As already noted in the preceding pages, the yellow stained oxidized ore passes into an ore in which the quartz is no longer translucent and solid but is opaque, white, and more or less saccharoid, and often porous, while the fragments of included schist have been changed by the acid waters to a white, clayey material. Specimens of this ore collected by me show the lower tip of a vertical "pipe" of oxidized ore surrounded by the altered but not yet oxidized ore. In the latter mineral black, sooty masses are seen whose form and distribution accord exactly with those of the chalcopyrite in the unaltered primary ore. The yellow stained oxidized ore differs in showing about its borders a band of massive crystalline glance often mixed with cuprite, the oxide predominating toward the very sharp line marking the limit of the yellow iron stained ore. The specimen shows that there has been a transposition of material and a redeposition of the copper as glance. This border or halo of enrichment is very common in the ore from this mine. In the more perfectly oxidized and iron stained ore the cuprite is changed to malachite, and the latter sometimes to chrysocolla. In other specimens from Gold Hill the altered white quartz carries copper glance, beautiful crystalline cuprite, and native copper. The glance occurs not only scattered through the ore but in little clusters of crystals through the clay and rotten quartz. Other specimens show massive crystalline glance a quarter of an inch thick coating the specimen, the surface of the glance coated with a very thin or felty covering of native copper.

In the main body of the vein there are also bunches several feet in diameter of massive, coarsely crystalline quartz. In this material the chalcopyrite is in masses an inch or more across. Where this ore has been altered the chalcopyrite has been changed directly to massive glance showing a crystalline texture, and the quartz about it is more or less iron stained and the glance surrounded by a film of red oxide of copper changing to fibrous malachite along cracks in the quartz.

In ores from Copperopolis, Meagher county, Montana, glance also 
occurs secondary after cupriferous pyrite, as shown by several specimens. The ores of the copper-bearing diabase dikes of the "Blackfoot ceded strip" in northern Montana also show this same alteration, with specular iron ore accompanying the glance.

Bornite altering to glance is a common feature of the ores of the Virgilina field in Virginia and North Carolina. Specimens from the Blue Wing mine show bornite cracked by minute fissures, along which alteration has taken place and left rounded cores of bornite surrounded by a shell of dull, conchoidally fracturing glance with iron oxide outside of this. The specimens taken below the level of permanent water show the bornite altered to chalcocite and the iron concentrated in nests of laminated specular iron ore.

The evidence showing the secondary nature of these copper minerals has been summarized from a large mass of material, for while many writers have assumed the secondary character of ore deposits formed of these minerals, no evidence has been given on which to base a judgment, and the facts have lately assumed a great economic importance in the legal fight now being made for the possession of several of the great copper veins at Butte, Montana.

The evidence of a secondary origin of other metallic sulphides is less abundant, but quite sufficient to be convincing. The first writer to describe the general occurrence of such minerals appears to be Walter P. Jenney, who notes their appearance in the lead and zinc deposits of the Mississippi valley.* $\mathrm{He}$ ascribes the formation of secondary sulphides of lead and zine to the descending oxidized solutions which leach the upper parts of the original ore body. He says:

"The minerals of secondary deposition are sulphides-pyrite and marcasite derived from the iron of the wall rocks; blende, galena, chalcopyrite, and greenockite produced by alteration from the primary ores in the zone of oxidation in the upper portions of the ore bodies and reformed as sulphides by the reducing action of organic matter in the deeper levels. In addition to these sulphides, sulphates, carbonates, silicates, and phosphates also occur, the most abundant being now anglesite from the alteration of galena. Barite occurs locally, probably derived from a gangue of the ore. Soluble sulphates of zinc, iron, and other metals are also found in the drip of the mines."

In discussing the order of deposition of the minerals he states that minerals of secondary deposition vary in their paragenesis, and the same mineral may occur more than once in the series. Though conforming to no absolute order, the prevailing sequence is as follows:

1. Crystallized white and rose-colored dolomite lining cavities in the ore body and filling interstices in the breccia. 
2. Crystallized blende, usually of garnet or ruby red color, often in small, brilliant, translucent crystals; crystallized galena.

3. Crystallized pyrite, marcasite, chalcopyrite, calcite, barite, and amorphous tallow clay.

4. Anglesite, cerussite, calamine, smithsonite, and greenockite resulting from the alteration of the ores.

It may be noted that the primary ores are composed almost wholly of simple sulphides of zinc and lead and of the gangue minerals dolomite and cherokite (crystalline silica with spots of bitumen). Calcite appears to be in all cases of secondary and late formation. Pyrite, marcasite, and barite are probably of both primary and secondary deposition, but are of subordinate importance.

In personal conversation upon the subject Mr Jenney tells me that the tests made for him of these redeposited sulphides show that the secondary minerals are always much purer than the primary ones; thus the blende, which is always colored by impurities in the primary ore, is almost pure and translucent in the redeposited form. The galena also is much purer in the secondary form.

In the paper quoted he says :*

"The perfect faces and sharp edges of crystals of blende and galena found lining the water channels in the lower parts of the ore body show that below the zone of oxidation no solution or decomposition of the metallic sulphides takes place. Even where the lead and zinc become oxidized and pass into solution in the circulating waters, contact with the organic matter contained in the rocks in the presence of alkaline sulphates, which occur in all mineral waters, immediately reduces and precipitates the metals as sulphides.

$$
\mathrm{PbO}, \mathrm{CO}_{2}+\mathrm{CaO}, \mathrm{SO}_{3}+\mathrm{H}_{2} \mathrm{O}+2 \mathrm{C}=\mathrm{PbS}+\mathrm{CaO}, \mathrm{CO}_{2}+2 \mathrm{CO}_{2}+\mathrm{H}_{2} \mathrm{O} \text {. }
$$

" It is this protective action of the organic matter disseminated through the strata that has limited the zone of oxidation to so shallow a depth in the mining regions, for until all the carbon contained in the rocks is first consumed by oxidation, no decomposition of the minerals can occur or any segregation of minerals take place."

In the discussion of this paper, further notes are also given upon this process : $\dagger$

"The only deposition now taking place is that resulting from oxidation of the previously existing ores and their reformation due to the secondary action of oxidizing surface waters precolating downward through the upper portion of the ore bodies. Stalactites of blende, galena, and marcasite, not infrequently of calamine, smithsonite, and cerussite, occur in the vugs and open channels in the ore bodies, but they all appear in all observed instances to have been formed by the secondary action of surface waters in the primary ore." 
In a memoir on the silver deposits of Neihart, Montana, I have described* the paragenesis of the ore and gangue minerals. From a careful study of the order of superposition of the minerals in distinct crusts, and in crystals upon earlier minerals, supplemented by that of thin-sections of the ores, it was found that galena, pyrite, and blende, which form the primary ore minerals, are decomposed, and that the silver is concentrated, together with arsenic and antimony, as polybasite and dark, ruby silver, and more rarely pure, transparent blende, pure galena, and pyrite are deposited as secondary minerals. The thin-sections show galena altering to spongy polybasite. Both polybasite and pyrargyrite occur on all other minerals as crystalline aggregates and crusts and are not in any case coated or dotted by other minerals. Some of the material shows that the deposition of these silver minerals is still going on in water holes below the normal water level at the Florence mine at Neihart. As described later, the occurrence of the minerals also affords good proof of their secondary character.

\section{SUMMARY OF CHEMICAL AND MINERALOGIC EVIDENCE}

The evidence afforded by a study of the original unaltered ore and of ore in various stages of alteration, together with that of the superficial waters draining masses of such ore, show that the original ore is leached by surface waters which take into solution the various metals, and, trickling downward, meet with and are decomposed by the sulphides of iron present in the unaltered ore below and deposit new sulphides of the metals. The copper, silver, and gold contents of the original ore are thus concentrated, usually with antimony and arsenic.

The mineralogic evidence shows that the chemical precipitates formed by the foregoing reactions are true minerals, and the study of hand specimens and of microscopic slides confirm the chemical changes outlined.

\section{Mode of Occurrence of Deposits of Secondary Sulphide Orfs}

\section{METHOD ADOPTED OF PRESENTING THE SUBJECT}

In the following pages the occurrence of masses of exceptionally rich sulphide ores, such as copper glance, polybasite, ruby silver, etcetera, will be noted, and it will be shown that these facts prove the secondary nature of the ore. The genetic association of ores of this character with direct superficial alteration or secondary post-vein fractures will be in-

*Geology of the Little Belt mountains, Montana, with notes on the Neihart, Barker, Yogo, and other mining districts of the region, Twentieth Ann. Rept. U. S. Geological Survey, 1899-1900, pp. 257-572. 
dicated. The geologic evidence comprises the facts showing the position of the ores of the vein, their relation to structural or physical features, and the alteration of the ore bodies as masses in contradistinction to purely mineral alteration.

For convenience of presentation the different ores have been grouped according to the predominance of their principal ore. This treatment necessarily involves a slight repetition, since silver often occurs with copper and lead with zinc.

\section{COPPER}

For many years past there appears to have existed among mining engineers and a few geologists a tacit and sometimes an openly expressed belief in the secondary derivation of many deposits of copper glance. This statement is based on a review of the published accounts of a number of copper deposits in which such an origin has been either implied or stated, though, as a rule, no evidence has been presented.* This belief, if it may be so called, has undoubtedly had its origin in the descriptions of the Ducktown, Tennessee, deposits, which are described in all the text-books on ore deposits. The mass of rich "black copper" ore lying between the limonite gossan and the unaltered pyrrhotite has been stated to be of secondary origin ever since 1856, when Whitney published his now classic work on "The Metallic Wealth of the United States." In accounts of these deposits by Sterry Hunt, Hermann Credner, Carl Henrich, and lately by Professor Kemp the secondary nature of these ores has not been questioned, and the commonly accepted theory of their origin has been the leaching of the former lean sulphide ores, now altered to gossan, and the redeposition of the copper to form the rich black copper ore. Recent studies of the copper deposits of the West have made it desirable to review the evidence on which this theory rests, and to ascertain if bodies of crystalline sulphides have been formed by such action I made a visit to this locality in December, 1899. As is well known, the conditions prevailing at Ducktown are peculiarly favorable for a leaching of the gossan zone. Rainfall is frequent and heavy, and an altitude of 1,700 feet above sealevel favors rapid and considerable changes in temperatures. Moreover, the region has not been glaciated, and the gossan zone has presumably been forming since the elevation of the Tertiary peneplain, to which the district belongs. The following extracts from the more important papers describing this locality will, it is believed, serve better than an account by me to show the occurrence and nature of the secondary ore.

* See Kemp : Ore deposits of the United States, 2d ed, New York, 1896, p. 164. 


\section{Sterry Hunt wrote :*}

"The curious phenomenon of the occurrence of the black ores in these deposits between the gossan above and the unchanged pyritous ores beneath has often been described, and there seems no reason to question the receired explanation that they owe their-origin to the reduction, in some imperfectly explained way, of the sulphates formerly generated by oxidation in the upper portion of the lodes, which, as is well known, is changed into a porous mass of hydrous peroxide of iron holding more or less oxide and green carbonate of copper in its lower portions. Pyrrhotine is not without action on copper solutions, and its agency has been, with great probability, suggested by Professor Henry Wurtz as accounting for the precipitation of copper sulphide."

Secondary ores are described as consisting chiefly of sulphides, sometimes with an excess of iron, but more commonly with a large percentage of copper oxide. They are said to approach copper glance in composition, and it is said that crystals of glance have been observed by $\mathbf{M r}$ August Raht in this ore, which at times approaches bornite and chalcopyrite in composition, and held in it grains of copper or crystals of red oxide.

"It is commonly impregnated with copper sulphate, the drainage waters from which contain large quantities of this salt. As high as 5,000 pounds a month of cement copper have been obtained from these waters, in which the percentage of copper is about .001."

Henrich, in a paper on the Ducktown ore deposits, $\dagger$ says :

"The black copper found below the gossan had a very little black copper ore or tenorite (CuO) in its composition. Most of the copper in it probably occurs as copper glance, giving to it the black color. Native copper and cuprite are occasionally present; malachite and silicates were found usually near the edges of the black copper ore bodies, and in seams and stringers in the lower part of the gossan. The walls alongside of the black copper zone were penetrated by seams and fissures extending 5 to 12 feet from the ore body and carrying green carbonates."

The following analysis made by Doctor A. Trippel is quoted by sev-. eral authors in their descriptions of the Ducktown deposits :

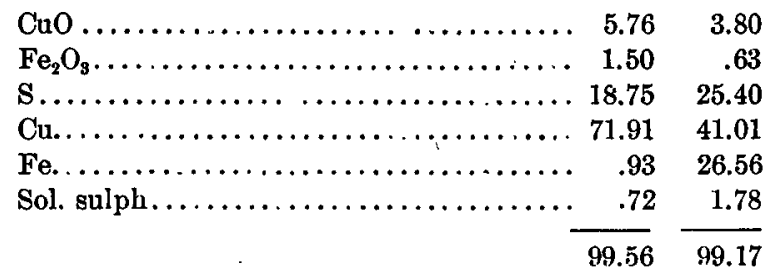

*'Trans. Am. Inst. Mining Engineers, vol. ii, 1874, p. 127. † Ibid., March, 1895, p. 37. 
I examined the old black copper workings at Ducktown and found that the layer of this ore conformed in a general way to the surface contour of the ground or more nearly to the surface of the underground waters. The accumulation of the ore in a well defined band or layer is believed to be due to the massive nature of the original ore, which is unusually free from vertical fissuring such as would afford aceess for waters to seep downward, while it does show flat or gently inclined fracture planes. The occurrence of the black ore, its impregnation with copper sulphate, the fact that it is generally moist with strongly acid water, all show that the process is still going on, and indeed, in small clefts in the upper surface of the pyrrhotite ore, what appeared to be recently deposited amorphous black copper ore was found. No crystalline ore was found in place, nor has any been seen in specimens of the ore in various collections. The deposit appears to be wholly a loose textured sintery mass of amorphous copper sulphide, often containing a residual skeleton of pyrrhotite. It is not, however, tenorite $(\mathrm{CuO})$; nor has any tenorite been found in numerous samples from the Ducktown region tested by or for me.

The Stone Hill (Alabama), Ore Knob (North Carolina), and Hillsville (Carroll county, Virginia) copper mines. all of which closely resemble the Ducktown deposits in occurrence and character of ore,* also showed the same enrichment-a layer of "iron black friable. drusy, crystalline sulphuret ore inclosing grains of quartz, garnet, magnetite, and a black non-magnetic mineral. This ore carried 36 per cent of copper and had the mineralogical character of purple and vitreous ores." $\dagger$

In Arizona oxidized ores of copper are described as passing in depth to chalcocite, and this into chalcopyrite below, at the Coronado vein, $\ddagger$ and in minor deposits near Bisbee. $\S$

The first statement that secondary enrichments of copper veins were of general occurrence, and that the ores consist of crystalline glance and bornite, appears in a paper by De Launay.\| He says chalcopyrite and cupriferous pyrite alter to bornite, chalcocite, cuprite, and gray copper, which form deposits that do not extend far in depth. The deposits of Monte Catini, in Tuscany, those of Rio Tinto and San Domingo, in Spain, and Butte, Montana, are cited as examples. The secondary nature of the last mentioned deposits is also maintained by Emmons in a report

* Sterry Hunt: Trans. Am. Inst. Mining Engineers, vol. ii, 1874, p. 123; E. E. Olcott, in Trans. Am. Inst. Mining Engineers, vol. iii, p. 391 ; R. P. Rothwell, in Engineering and Mining Journal.

† Hunt: Trans. Am. Inst. Mining Engineers, 1874, p. 123.

$\ddagger$ A. F. Wendt: Trans. Am. Inst. Mining Engineers, vol., xv, p. 52.

8 James Douglas: Copper resources of the United States. Trans. Am. Inst. Mining Engineers, September, 1891.

Annales des Mines, vol. xii., 1897, pp. 191-195. 
upon the ore deposits of that district.* He has suggested that the secondary deposition or transposition of the copper minerals at the Butte (Montana) mines may have been produced by waters descending from the surface. He says further :

"Secondary deposition, or transposition of already deposited minerals, has played an unusually important role. In the case of the copper veins it has not been confined to the oxidizing action of surface waters, which has resulted in an impoverishment of the ore bodies, but below the zone of oxidation it has resulted in the formation of the richer copper minerals, bornite, chalcocite, and covellite, in part at least, by the breaking up of original chalcopyrite. Unusual enrichment of the middle depths of the lodes has thus been caused. Whether the two processes of impoverishment and enrichment bave been differing phases of the action of descending waters, or whether the latter may have been a later result of the rhyolite intrusion, has not yet been definitely decided. It is, however, fairly well determined that the enrichment of the copper deposits is so closely associated with the secondary faulting that it may be considered to be a genetic result of it.

"In the silver veins surface oxidation has resulted in general in the enrichment of the ore bodies. No certain evidence of secondary eurichment in the sulphide zone of these ore bodies was obtained."

A very important contribution upon this subject has recently appeared, entitled "A Description of the Pyrite Deposits of the Huelva Region in southern Spain and the adjoining Portions of Portugal," in which Dr J. H. L. Vogt $\dagger$ says that the amount of copper in the pyrite of these ore bodies becomes in a general way less and less with increasing depth at the San Domingo mine. The ore which at the surface has 4 or 5 per cent of copper contains at a depth of 80 meters but 2 per cent. At 100 meters the copper contents has fallen to $1 \frac{1}{2}$ and $1 \frac{3}{4}$ per cent, while at 130 meters in depth the ore holds only about 11 per cent. In the ores of the Dionisio mine the percentage, which is 4 per cent in the upper levels, has fallen to 2 per cent at 200 meters and to $2 \frac{1}{2}$ per cent at 350 meters. It is to be understood, he says, that the copper contents in different parts of the respective levels will vary somewhat, though the average contents always grow less in depth.

This impoverishment in depth has also been discussed by Klockmann. $\ddagger$ He coincides with the view held by all the Spanish geologists, and says this constant decrease in depth of the copper contents is due to the fact that the original copper contents of the pyrite of the uppermost part of the vein went into solution through weathering, and that the copper-bearing solution then seeped down along cracks and fissures into the deeper lying pyrites. It there formed a new generation of

* Butte Special Folio, folio.39, U. S. Geological Survey, 1898,

† Zeitschrift für Praktisehe Geologie, July, 1899.

$\ddagger$ Ibid., 1895, p. 35 . 
minerals rich in copper; in fact that they do often find copper glance, bornite, and chalcopyrite, together with galena, zinc blende, tetrahedrite, etcetera, usually accompanied by some quartz, in the cracks and fissures in the pyrite, and these minerals are, without doubt, of younger, secondary formation. These secondary ores sometimes fill the cracks so large that they can be separately mined, and the mining done by the Romans was chiefly confined to these rich streaks within the poorer mass of pyrite. More commonly, however, the rich ores occur in quite small fissures which form a branching network in the main body of pyrite. That the copper contents of these secondary minerals has been derived from the weathered ore near the surface is shown quite clearly by the fact that these little veins are most common in the zone immediately under the gossan. They usually extend to some 100 meters or more in depth, while below this the pyrite is firm, little cracked, and comparatively poor in copper. In discussing these observations Professor Vogt says :

"The enrichment described by Klockmann of the copper contents of the upper part of the ore bodies undoubtedly plays a very important role. From my own examination of the different mines I have obtained, however, the impression that this process alone was not sufficient to account for the phenomena described, and that the decreasing copper contents in depth is in part of a primary nature."

For the sake of analogy he also mentions the fact that the copper contents of the ore body of the Vigsnas mine in Norway, which is now known to have a depth of 735 meters, becomes less in depth, and that this is also the case at Fahlun, where the pyrite body has been worked to a depth of 350 meters.

At Gold Hill, North Carolina, the workings of the Union Copper company show very fine examples of secondary sulphide enrichment, but there is no well defined zone or continuous mass, as the veins are fractured by vertical fissures. The unaltered ore is chalcopyrite, which occurs in quartz veins traversing schists, following the foliation in part. The ore occurs only in the quartz, which forms lenticular masses, as is commonly the case in schistose rocks. The veins have been worked during the 40 or 50 years past, the deepest openings being 800 feet. They were worked as gold properties, but showed an increase of copper in descending which prevented amalgamation and led to the closing down of the property. The Union Copper company is now working several of these veins, one of them, the Big Cut copper vein, yielding considerable ore, which has been shipped. Superficial alteration has rotted and decomposed the upper part of the vein so that it closely resembles the saprolites of the adjacent schists, though redder in color. 
This changes in depth to a rusty, earthy, silicious mass, holding carbonates, oxides, and native copper, passing downward into black sulphuret, and this to the unaltered sulphide. These changes are generalized, since there is no definite level of any one kind of ore. Owing to vertical fracturing, the upper and lower limits of the brown stained oxidized ore are very irregular. 'This is especially true of the lower limit, channels and pipes of oxidizing waters extending down 180 feet or more below the surface and half that distance into solid, unaltered quartz ore. The zone of enrichment marked by chalcocite, in part altered to cuprite, is therefore not well defined, the secondary sulphides being scattered about in accordance with the irregularities of the water line.

At the very interesting copper veins of the Virgilina district of Virginia and North Carolina no evidence on secondary enrichment was obtained, as the quartz veins carry chalcocite and bornite and near.the surface the superficial alteration products of these minerals. The deepest shaft is now but 300 feet down, and it will be interesting to see if the glance changes to chalcopyrite in depth. The bornite is seen altered to glance and hematite below the zone of oxidation by the surface waters. This and the general absence of either pyrite or chalcopyrite from the glance are quite unlike other deposits of the east, and, in fact, of the west.

Specimens of glance from the Gila river, Arizona, kindly given me by Mr S. B. Ladd, are similarly free from pyrite or chalcopyrite, but both this material and that of Virgilina are distinctly crystalline and lack the dull fracture and structure of Butte ores. In the "Blackfoot ceded strip," on the east side of the fruit range in northern Montana, dikes of diabase traversing Algonkian slates carry copper ores. The original chalcopyrite is seen cracked and fissured with alteration chalcocite.

\section{$S I L V E R$}

The "bonanzas" of rich silver ores like those of the Smuggler and Mollie Gibson mines of Colorado, and of silver-lead or pyritic ores carrying ruby silver, polybasite, or silver glance, are believed to be, in many if not most cases, examples of secondary deposition.

The first writer to call attention to secondary enrichment of silver veins is De Launay. In discussing the superficial alteration of silver deposits he gives a summary of his views,* from which the following extract is taken :

Near the surface the silver in the veins is in the native state, with chlorides, bromides, iodide, etcetera, associated with oxide of iron, manganese, and often of copper. If the gangue is silicious, it shows a porous honeycomb aspect, resulting

* Ann. des Mines, rol. xii, 1897, p. 221 . See also description given in L'argent, p. 96. 
from the removal of the sulphides which it formerly held. Frequently, too, the red and gray silver ores are associated there. These ores are the pacos, chlorides, etcetera, of the Spanish-American miners.

Deeper down, at 80 to 150 meters, the bonanza zone is encountered, where the silver is in the form of glance $\left(A \mathrm{~g}_{2} \mathrm{~S}\right)$, the copper as chalcocite, gray copper (often argentiferous), and bornite. Iron is wanting or is present as oxide. Lead, if present, is in small amount and mostly in the form of the carbonate.

Still lower beneath the ground water level, which varies from 400 to 500 meters, one finds a complex assemblage of primitive metalliferous sulphides, galena, which is more or less argentiferous, copper and iron pyrites, arsenopyrite, blende, and rarely silver minerals.

In the secondary ores of copper, gold and silver, which are commonly present in small amounts in copper ores, are concentrated in gray coppers or as native gold or silver, which we see commonly in bornite.*

Professor Vogt also describes $\dagger$ the recent formation of a gold and silver bearing zone beneath the iron hat. He says that in the Rio Tinto region the "iron hat" is from 35 to 50 meters deep, and consists of iron oxide or hydrated oxide, with from 35 to 50 per cent of iron, some silver in part as basic sulphate, and a few ten-thousandths per cent of arsenic, while on the other hand the copper contents are, as already remarked, entirely oxidized and dissolved out. In one mine, North vein number 2, at Rio Tinto, there occurred between the "iron hat" and the underlying comparatively fresh pyrite a layer of earthy, porous material bearing gold and silver. This earthy ore, though a few decimeters in thickness, may be followed continuously over the entire ore body. 'This very marked layer follows closely the irregular plane between the "iron hat " and the underlying pyrite. It every where contains an average gold and silver contents of from 15 to 30 grammes gold and 1.025 silver, with a value of about 150 marks per ton. In stripping off the "iron hat" this earthy mass is carefully laid to one side, and has thus yielded fully a thousand tons of ore. It is clear that the formation of this gold and silver bearing zone is connected with the oxidizing process that formed the "iron hat," and that the gold and silver comes from the very small percentage of such metals in the primary ores.

Another interesting structural feature of silver bonanzas is their occurrence in connection with faults or later fractures. This is also true in the copper mines of Butte, as pointed out by Emmons. It is probably true in the Broken Hill Consolidated mines, Australia, and in the Aspen district, Colorado.

In his monograph on the Aspen district, Colorado, Mr Spurr $\ddagger$ de-

* De Launay, loc. cit., p. 195.

† Zeitschrift für Praktische Geologie, July, 1899.

f J. E. Spurr: Monograph no. xxxi, Aspen mining district, U. S. Geological Survey. 
scribes the occurrence of the famous ore bodies of the Smuggler and Mollie Gibson mines at Aspen. The ore consists of barite and polybasite, with tennantite. Although Mr Spurr gives no definite statements as to the possible secondary origin of these ores, yet the sketch which he gives on page 183 and the descriptions all indicate that the original ore was a silver-bearing lead sulphide, with more or less zinc sulphide, formed along inclined faults, and that subsequent to the formation of these ore bodies nearly vertical faults displaced the ore and formed the two bodies now worked at the mines mentioned. Although in these vertical or nearly vertical fissures rich polybasite ore is now found, it does not extend far in either direction from this fault, and the description of the ores given by Mr Spurr indicates that it is derived by secondary alteration processes from the lead and zinc ore bodies. This also is indicated by the fact that the polybasite is in part altered to native silver at the extreme lower end of the ore body.

In conversation $\mathrm{Mr}$ Spurr has admitted the possible secondary origin of these polybasite bodies, but he has no new evidence upon the subject. He says:

"This ore was of a rich character, having large amounts of polybasite and native silver. This polybasite body appears to lie in a sort of subordinate shoot, trending south of east and lying at the Gibson fault plane. This shoot is marked by exceptionally large and rich bodies of a nature not found elsewhere in the mine. It is noteworthy that this rich shoot is practically the lower termination of the ore of the Gibson fault. Most of the ore below this is native silver, which, from the nature of its occurrence, is manifestly a secondary deposit leached from the rich ore above. Some of these secondary deposits are, however, of considerable size, and empty vugs are often found beautifully and elaborately festooned with delicate wires of silver. Above the polybasite ore, however, the ore appears to be pretty continuous, but the amount of silver becomes less."

It will be noticed that he recognizes the secondary nature of the silver. and that the polybasite lies between the native silver and the lead surface,

In his chapter on the chemical geology of the region, where he discusses the alteration of the ore deposits and of the limestones, he does not adduce any new facts concerning the formation of the polybasite ore, but he does state that iron pyrites carrying small amounts of arsenic, lead, copper, zinc, cadmium, cobalt, and nickel are found, and that tetrahedrite is also very common. The polybasite is said to be later than the barite.

A very interesting and remarkable case of secondary enrichment occurs at the Broken Hill Consolidated mine, Australia, described by $\mathbf{M r}$ George Smith.* MrSmith shows by his description and sketches that the 
lode carrying the ore faults earlier veins, and that the lode worked is rich only where such intersections occur. He says: "All the evidence yet produced by the mine's development points to an essential connection between the ore deposits and cross-veins." His explanation of electric currents seems to be unnecessary, but may well supplement a leaching of the earlier vein and the concentration of material at the point shown. It is significant that the ore occurs under the vertical vein, as shown in his figure, and not above its faulted portion.

The only examples of secondary sulphide enrichment of silver veins which I have carefully studied are those of Neihart, Meagher county, Montana. The Neihart ore deposits occur in metamorphic gneisses of supposed igneous, origin and Archean age, and extend upward into the basal beds of the Belt series of Algonkian age. They are sheeted fissures that cut both ancient and recent igneous rocks, and are believed to be of post-Cretaceous age.

The veins contain silver-lead ores; more rarely rich silver sulphides. The ratio of gold and silver is one dollar in gold to 5 ounces of silver. The common ores consist of galena, blende, and pyrite in a gangue consisting of lime-magnesia-iron and manganese carbonate. The rich silver ores consist of polybasite, with a lesser amount of pyrargyrite, and in the oxidation zone of native silver chalcopyrite also occurs. Barite is a common gangue mineral, but occurs in much smaller quantity than the carbonate "spar." The primary ore minerals are those mentioned above, excepting perhaps pyrargyrite. Polybasite more commonly occurs, however, as a secondary mineral.

The silver-lead ores vary from $\$ 20$ to $\$ 60$ per ton; the richer ores $\$ 100$ to $\$ 200$ or more per ton. The vein fissures are part of a general fissure system, running about north and south magnetic, and dipping west at 60 to 80 degrees. The width of the fissure varies in the different rocks. It is widest in the softer schistose rocks, narrow but sharp cut in the massive diorite, is irregular and narrow in tough and knotty amphibolites, and becomes lost in a multitude of little fissures in rhyolite porphyry.

The veins are commonly zones of closely sheeted rock. This rock is intensely altered and decomposed, and the vein walls practically limit this alteration. The ores occur in more or less persistent streaks of carbonates or "spar," and rarely show quartz in this altered rock or vein matter. The payable ore bodies occur in shoots. Ore deposition was by ascending carbonated waters, producing metasomatic replacement along fissure lines. The veins have suffered later fracturing and secondary enrichment of the zone has occurred at or below the water level, while quartz and barite have been deposited in the open spaces of some 
of the veins, being usually accompanied by rich silver sulphide ores showing marked crustification.*

The secondary deposition of rich silver sulphides has played an unusually important part in the ore deposits of Neihart, Montana. In these veins it consists of a breaking up or decomposition of the primary ore minerals, chalcopyrite, pyrite, and an impure argentiferous galena, of the lode, and the formation of the rich silver minerals, polybasite, pyrargyrite, with secondary pyrite and blende. These secondary minerals are always found in connection with open water pipes or with postvein fractures, are often well crystallized, and occur commonly with recent quartz in vugs and 'along open fractures by which descending waters could trickle downward.

The products of superficial alteration are largely removed, and the zone of gossan or the barren leached lode is less than 50 feet deep, or may not exist. Beneath this leached and impoverished part of the lode there is generally an irregular accumulation (sometimes regular enough to be called a layer) of a sooty, black ore consisting of manganese and silver sulphide, the material often being quite rich in silver. In the rhyolite porphyry, where the veins are not well defined but are a mass of shattered rock, the crevices for 40 to 100 feet or more downward are filled with this material. Where the lode is well defined the secondary antimonial sulphides occur below at first in considerable abundance, but deeper down only in crevices and fissures, partly or wholly lining filled fractures, so that they become less and less abundant in going downward on the vein. There is therefore an unusual enrichment of the upper part of these veins-that is, of what is now the upper part.

The transposition and redeposition of ores with enrichment in silver can be easily conceived to take place by means of water-courses conveyveying the deoxidized surface waters to considerable depths, a common feature in many of our western mines.t The ruby silver of the Trout and Hope mines and the rich sulphides of the Granite Mountain mine, near Phillipsburg, Montana, 2,000 feet below the surface, associated with clear evidence of partial oxidation, are examples seen by me. The very rich ores of the Ruby mine on Lowland creek, near Butte, Montana, and the high grade ore shoot of the Hope mine of Basin, Montana, show geological conditions suggesting a similar origin. Microscopic examinations

* The foregoing description is an abstract of a chapter on the Neihart ore deposits forming part of a report on the geology of the mining distriets of the Little Belt mountains, Montana. Twentieth Annual Report, U. S. Geological Survey for 1898-'99, part tii, p. 403.

+ These water-courses occur at Elkhorn, Montana, 2,000 feet below the surface. That they are the channels of descending waters is clearly proved by the main workings, although the permanent water level of the country is only a short distance below the ground, and the oxidized ores extend down for $600-700$ feet only. The rocks are limestone. 
of thin-sections of the Drum Lummon ore, Marysville, Montana, seem to indicate a secondary origin for the extremely rich silver-gold ores of that lode.

In the first few years following the discovery of the enormously rich placer deposits of Montana many discoveries of rich silver-bearing lodes were made. These held enormously rich deposits of silver sulphides and sulphantimonides beneath the shallow layer of oxidized ore; but these enrichment deposits, which led to most extravagant ideas of the future of this region, were soon exhausted, and when the leaner, baser, primary ores were encountered work was usually suspended.

\section{ZINC}

The secondary origin of bodies of zinc blende at Leadville, Colorado, has been maintained by Blow,* who, in describing their occurrence there, writes :

The zinc sulphides are the most widely disseminated and show plainly the result of their more ready solubility than the other sulphides and the redeposition of a large portion of the zinc which has thins been removed from the carbonate ores. This fact is clearly shown in many ways, but most satisfactorily just at the line of transition. The sulphides first encountered are invariably heavy sulphides of zinc, carrying a little iron and very little lead. They have a close crystalline structure and lie in a laminated form, the lines of fracture being nearly vertical. Upon these cleavage planes crystals of cernssite are found, and often a small incrustation of native silver. Such deposits, where first encountered in passing from oxidized to unoxidized ores, are always lowest in silver. In their further extension the zine gradually grows less and the laminated structure disappears. Beyond this, again, the zinc sulphides appear to predominate along cleavage and contact planes with the gray porphyry or along the lines of minor faults and cracks in the limestone. Such characteristics are also universally observed in other instances besides those of Iron Hill.

It seems probable that a large proportion of the zinc, which was totally removed from the carbonate ores, has been redeposited as a sulphide, and principally just below the line of complete oxidation, by surface waters, and such redeposition has advanced and increased pari passu with the limit and extent of such oxidizing action.

As a corollary of the above, it is believed that at the present stage of development in Leadville the sulphide of zinc forms a larger part of the unoxidized ores than will be found in future and deeper exploration.

There is also evidence going to show that the action of alteration and secondary deposition has extended for a considerable distance within the sulphide bodies. In ores of this class the silver values are found concentrated, as it were, with preponderance of either the zinc, lead, or iron occurring in lenticular masses or patches, surrounded by low grade ore, and forming bonanzas of great value. These bonanzas are rarely found near the flanks or sides of the chute, but generally in its center and with no connection one with another.

* A. A. Blow, in Trans. Am. Inst. Mining Engineers, June, 1889. 
The notes by Jenney and Iles mentioned show that secondary zinc sulphide is formed at other localities. The writer has also seen zinc blende as a later formed mineral incrusting fractured primary ore and resting on secondary quartz and pyrite in specimens from Neihart, Montana. This secondary blende differs greatly in appearance from that of the primary ore, being translucent, with well formed individual crystals, while that of the older generation is dark colored, impure, massive, and generally fractured.

\section{Conclusions}

From what has been shown it is concluded that later enrichment of mineral veins is as important as the formation of the veins themselves, particularly from the economic standpoint. The enrichment is usually due to downward moving surface waters, leaching the upper part of the vein and precipitating copper, silver, etcetera, by reaction with the unaltered ore below. In many cases the enrichment proceeds along barren fractures and makes bonanzas. In others it forms films, pay streaks, or ore shoots in the body of leaner original ore. In still other cases the leaching, transposition, and redeposition are performed by deep seated uprising waters agting upon the vein.

As a consequence of this, veins do not increase in richness in depths below the zone of enrichment.

The practical bearing of the phenomena described and the deduction drawn from them will, I think, be apparent to every mining engineer and geologist. If my views be correct, the future of many ore deposits is to be judged in the light of these facts, and the value of the mine must not be based on the presumption that the ore will continue in unabated richness in depth. 